\title{
Diversity and distribution of phytophagous and predatory mites on rosehip (Rosa canina L.) (Rosaceae) in Ankara, Turkey
}

\author{
Tuğba ERDOĞAN1,2 (D, Sultan ÇOBANOĞLU1 1 (D) \\ ${ }^{1}$ Department of Plant Protection, Faculty of Agriculture, Ankara University, Ankara, Turkey \\ ${ }^{2}$ Corresponding author: tugba.erdogan@ankara.edu.tr
}

ABSTRACT: The study was carried out to detect phytophagous and predatory mites on rosehip (Rosa canina L.) (Rosaceae) in Ankara, Turkey. The samples were collected monthly from Ayaş, Çubuk, Gölbaşı, Haymana, Kahramankazan and Kizılcahamam districts of Ankara province from March to November between 2012 and 2014. As a result, a total of 12 mite species were identified namely; Amphitetranychus viennensis (Zacher), Bryobia kissophila Eyndhoven, Eotetranychus populi (Koch), Tetranychus urticae Koch (Acari: Tetranychidae), Cenopalpus pulcher (Canestrini and Fanzago) (Acari: Tenuipalpidae), Tarsonemus smithi Ewing (Acari: Tarsonemidae) as phytophagous mites, and Euseius finlandicus (Oudemans), Kampimodromus aberrans (Oudemans), Paraseiulus triporus (Chant and Yoshida-Shaul), Typhlodromus (Anthoseius) bagdasarjani Wainstein and Arutunjan, T. (A.) psyllakisi (Swirski and Ragusa) (Acari: Phytoseiidae) and Zetzellia mali (Ewing) (Acari: Stigmaeidae) as predatory mites. Tetranychus urticae and K. aberrans are the most common phytophagous and predatory mites, respectively. Tarsonemus smithi is a new record for the Turkish fauna.

Keywords: Acari, mites, Phytoseiidae, Rosaceae, rosehip, Turkey

Zoobank: http://zoobank.org/E4047CC2-63A4-47E4-B00D-33BF30CD22A9

\section{INTRODUCTION}

Rosehip (Rosa canina L.) (Rosaceae) is a perennial, bushformed plant belonging to the family of Rosaceae. Rosehip is important for human health via regulation cholesterol and blood pressure. It has positive effect to decrease cancer disease, reduce the risk of getting diabetes. It is known it is beneficial at joint inflammation, increases blood pressure, protects skin and stomach health, and prevents kidney diseases. It is good for respiratory diseases (Anonymous, 2014). At the same time, for naturel rosehip is also grown as erosion preventive plants and as resource pollens of beekeeping. Rosehip, which is widely found in naturally in various regions of Turkey is a very rich plant group due to its minerals and vitamins.

There have been very few studies on arthropod pests of rosehip in Turkey (Karaca, 1956; Özbek et al., 1996; Bayram et al., 1998). Bayram et al. (1998) detected Diplolepis mayri Schlecht, D. rosae L. D. eglanteriae Htg. (Hymenoptera: Cynipidae) and Perrisia rosarum Hardy (Diptera: Cecidomyiidae) as pest species on the rosehip in Ankara (Center, Çamlıdere, Gölbaşı). Nine parasitoid species belonging to Braconidae, Chalcididae, Eulophidae, Eurytomidae, Pteromalidae and Torymidae families were also found in association with the above-mentioned pests in Turkey (Bayram et al., 1998). The mite species on rosehip have not been studied in Ankara province, so far. Therefore, the aim of this study was to determine diversity and distribution of phytophagous and predatory mites on rosehip (Rosa canina L.) (Rosaceae) in Ankara, Turkey.

\section{MATERIALS AND METHODS}

Samples were collected at monthly intervals from different districts of Ankara (Ayaş (GPS: 40.063466,
32.489552), Çubuk (GPS: 40.388507, 32.946036), Gölbaşı (GPS: 39.822684, 32.827995), Haymana (GPS: 39.616573, 32.692048), Kahramankazan (GPS: 40.184415, 32.666811) and Kizllcahamam (GPS: 40.459057, 32.624257)) during the period of March to November in 2012-2014 (Fig. 1). A total of 125 samples were collected from six districts in Ankara province during two years (14 samples from Ayaş, 33 samples from Çubuk, 16 samples from Gölbaşı, 15 samples from Haymana, 17 samples from Kahramankazan and 29 samples from Kizılcahamam). The plant samples were transferred to the laboratory and they were examined under stereomicroscope. Berlese funnels are also used to extract mites. The mites were cleared in lactophenol solution and then mounted in Hoyer's medium (Düzgüneş, 1980).

Species identifications were made by Prof. Sultan Çobanoğlu according to Pritchard and Baker (1955), Tuttle and Baker (1968), Jeppson et al. (1975), Meyer (1987) and Papadoulis et al. (2009). The identified specimens are deposited in the mite collection of senior author (University of Ankara, Department of Plant Protection, Ankara, Turkey).

\section{RESULTS AND DISCUSSION}

A total of 12 mite species belonging to five families were identified from rosehip in Ankara: Amphitetranychus viennensis (Zacher), Bryobia kissophila Eyndhoven, Eotetranychus populi (Koch), Tetranychus urticae Koch (Acari: Tetranychidae), Cenopalpus pulcher (Canestrini and Fanzago) (Acari: Tenuipalpidae), Tarsonemus smithi Ewing (Acari: Tarsonemidae) as phytophagous mites, and Euseius finlandicus (Oudemans), Kampimodromus aberrans (Oudemans), Paraseiulus triporus (Chant and Yoshida-Shaul), Typhlodromus (Anthoseius) bagdasarjani 
Wainstein and Arutunjan, T. (A.) psyllakisi (Swirski and Ragusa) (Acari: Phytoseiidae) and Zetzellia mali (Ewing)

Table 1. Phytophagous and predatory mites on Rosehip in Ankara

\begin{tabular}{|c|c|c|}
\hline & Family & Species \\
\hline \multirow{5}{*}{$\begin{array}{l}\text { Predatory } \\
\text { mites }\end{array}$} & \multirow{4}{*}{ Phytoseiidae } & Kampimodromus aberrans (Oudemans, 1930) \\
\hline & & Euseius finlandicus (Oudemans, 1915) \\
\hline & & Typhlodromus (Anthoseius) bagdasarjani Wainstein and Arutunjan, 1967 \\
\hline & & Typhlodromus (Anthoseius) psyllakisi (Swirski and Ragusa, 1976) \\
\hline & Stigmaeidae & Zetzellia mali (Ewing, 1917) \\
\hline \multirow{5}{*}{$\begin{array}{l}\text { Phytophagous } \\
\text { mites }\end{array}$} & Tarsonemidae & Tarsonemus smithi Ewing, 1939* \\
\hline & \multirow{4}{*}{ Tetranychidae } & Amphitetranychus viennensis (Zacher, 1920) \\
\hline & & Tetranychus urticae Koch, 1836 \\
\hline & & Eotetranychus populi (Koch, 1838) \\
\hline & & Bryobia kissophila Eyndhoven, 1955 \\
\hline
\end{tabular}

*New record for the Turkish fauna

A total of 1173 specimens, of which 897 specimens belongs to phytophagous mites, were identified. The six species are predators while the other six species are phytophagous mites (Table 1).

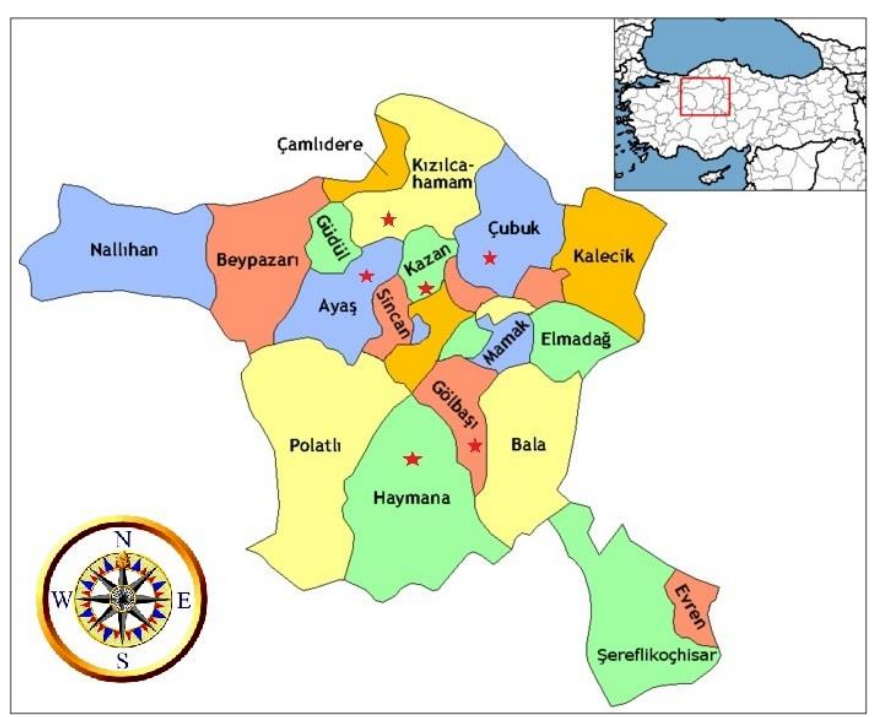

Figure 1. Ankara province ( $*$ : Sampling areas).

Phytophagous mites

Family: Tetranychidae

Amphitetranychus viennensis (Zacher, 1920)

Material examined: Çubuk, 02. VI. 2013 (1\%); Gölbaşı, 02. XI. 2013 (10 ); Haymana, 09. IX. 2012 (2\%\%); Kizılcahamam, 15. IV. 2012 (1\%), 26. V. 2013 (2\%).

Distribution: It is mostly seen in Asian and European countries (Migeon et al., 2011).
(Acari: Stigmaeidae) as predatory mites (Table 1). 
Netherlands, Poland, Portugal, Serbia-Montenegro, Slovakia, Slovenia, South Africa, Spain, Sweden, Switzerland, Tasmania (Australia), Turkey, Ukraine, UK, USA (Düzgüneş, 1963; Migeon et al., 2011).

Family: Tenuipalpidae

Cenopalpus pulcher (Canestrini and Fanzago, 1876)

Material examined: Ayaş, 06. VIII. 2012 (1\%), 21. IX. 2013 (19); Çubuk, 26. VIII. 2012 (1\%), 22. IX. 2012 (1\%), 25. XI. 2012 (1ㅇ), 28. IV. 2013 (19), 29. VI. 2013 (19); Gölbaşı, 06. I. 2012 (3ㅇ, 10'), 06. X. 2012 (4ㅇ), 04. XI. 2012 (1); Haymana, 17. VI. 2012 (1\%), 26. IX. 2013 (3\%\%); Kahramankazan, 16. XII. 2011(2\%\%); Kızllcahamam, 16. XII. 2011(2oㅇ).

Distribution: Afghanistan, Algeria, Austria, Britain, Bulgaria, Crimea, Cyprus, Denmark, Egypt, Georgia, Germany, Greece, Iranian, Iraq, Israel, Italy, Lebanon, Libya, the Netherlands, Portugal, Russia, Sicily, Syria, Turkey, Ukraine (Pritchard and Baker, 1958; Düzgüneș, 1965; Jeppson et al., 1975; Anonymous, 2007; Çobanoğlu et al., 2016).

Remarks: C. pulcher is frequently found in Gölbaşı, Çubuk and Haymana districts (Fig. 1).

Family: Tarsonemidae

Tarsonemus smithi Ewing, 1939

Material examined: Gölbașı, 06. I. 2012 (19).

Distribution: The species is widespread and known in North America, Japan, Germany, Israel, Poland, Crimea, Taiwan, Italy, Libya, China (Anonymous, 2016).

Remarks: Tarsonemus smithi is a new record for Turkish mite fauna.

\section{Predatory mites}

Family: Phytoseiidae

\section{Kampimodromus aberrans (Oudemans, 1930)}

Material examined: Ayaş, 13. V. 2012 (19), 08. VII. 2012 (20'0'), 19. V. 2013 (1\%), 27. VII. 2013 (3\%), 21. IX. 2013 (1ㅇ), 27. X. 2013 (3ㅇ); Çubuk, 03. VI. 2012 (2ㅇ), 01. VII.

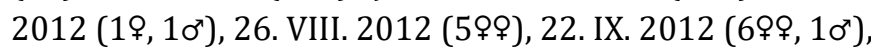
21. X. 2012 (3ㅇ), 25. XI. 2012 (2ㅇ), 25. VII. 2013 (1\%, $30^{7} \sigma^{\top}$ ), 21.VIII. 2013 (2\%)); Gölbaşı, 20. V. 2012 (9\%o), 06. X. 2012 (1\%), 04. XI. 2012 (1\%); Haymana, 20. V. 2012 (19), 01. V. 2013 (1\%), 13. VI. 2013 (19), 26. IX. 2013 (3\%)); Kahramankazan, 27. V. 2012 (5\%क), 23. VI. 2012

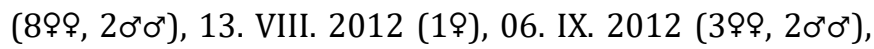
14. X. 2012 (3ㅇ), 14. IV. 2013 (3\%क), 26. V. 2013 (1\%), 21. VII. 2013 (6\%ᄋ); Kizılcahamam, 27. V. 2012 (1\%), 06. IX. 2012 (1), 14. X. 2012 (2\%क), 21. VII. 2013 (2\%).
Distribution: Albania, Algeria, Armenia, Austria, Azerbaijan, Belarus, Bulgaria, Canada-British, Columbia, Ontario, Caucasus Region, Croatia, Czech Republic, England, France, Georgia, Germany, Greece, Hungary, Iran, Israel, Italy, Moldova, Montenegro, Morocco, the Netherlands, Norway, Poland, Portugal, Russia-Krasnodar Region, Moscow, Serbia, Slovakia, Slovenia, Spain, Switzerland, Tunisia, Turkey, Ukraine, USA (Faraji et al., 2011; Demite, 2014).

\section{Euseius finlandicus (Oudemans, 1915)}

Material examined: Ayaş, 02. XII. 2012 (19), 21. IX. 2013 (1\%); Çubuk, 28. IV. 2013 (1\%), 02. VI. 2013 (1\%), 21. VIII. 2013 (1ㅇ), 16. IX. 2013 (3\%), 13. X. 2013 (2\%); Gölbaşı, 14. VIII. 2013 (6\%o); Haymana, 10. VIII. 2012 (2\%), 13. VI. 2013 (1\%); Kahramankazan, 14. X. 2012 (1\%), 18. XI. 2012 (2क\%); Kızılcahamam, 13.VIII. 2012 (19), 14. X. 2012 (169\%), 17. VIII. 2013 (1\%), 05. X. 2013 (19), 10. XI. 2013 (2우).

Distribution: Albania, Algeria, Angola, Argentina, Armenia, Austria, Azerbaijan, Belarus, Belgium, Bosnia and Herzegovina, Bulgaria, Canada, British Columbia, New Brunswick, Nova Scotia, Ontario, Caucasus Region, China, Croatia, Cyprus, Czech Republic, Denmark, England, Finland, France, Georgia, Germany, Greece, Hungary, India, Indonesia, Iran, Italy, Japan, Kazakhstan, Latvia, Lithuania, Mexico, Moldova, Montenegro, the Netherlands, Nicaragua, North Macedonia, Norway, Poland, Portugal, Russia, Scandinavia, Serbia, Slovakia, Slovenia, South Korea, Spain, Sweden, Switzerland, Turkey, Ukraine, USA (Faraji et al., 2011; Demite, 2014).

Typhlodromus (Anthoseius) bagdasarjani Wainstein and Arutunjan, 1967

Material examined: Gölbaşı, 10. VIII. 2012 (2ㅇ).

Distribution: Armenia, Azerbaijan, Iran, Turkey, Turkmenistan (Faraji et al., 2011; Demite, 2014).

Typhlodromus (Anthoseius) psyllakisi (Swirski and Ragusa, 1976)

Material examined: Ayaş, 06. VIII. 2012 (2\%̊); Haymana, 10. VIII. 2012 (19); Kahramankazan, 13. VIII. 2012 (1\%).

Distribution: Greece, Turkey (Demite, 2014; Ersin and Madanlar, 2016; Gökçe et al., 2020).

Paraseiulus triporus (Chant and Yoshida-Shaul, 1982)

Material examined: Çubuk, 01. V. 2012 (19).

Distribution: Czech Republic, Denmark, Finland, France, Georgia, Germany, Greece, Hungary, Iran, Italy, Kazakhstan, Moldova, Morocco, the Netherlands, Poland, Portugal, Russia, Serbia, Slovakia, Slovenia, Spain, Sweden, Syria, Turkey, Ukraine, USA (Demite, 2014). 
Family: Stigmaeidae

Zetzellia mali (Ewing, 1917)

Material examined: Çubuk, 21. X. 2012 (1\%); Kızılcahamam, 14. X. 2012 (19).

Distribution: Argentina, Austria, Bulgaria, Canada, China, Czech, France, Germany, Hungary, India; Iran, Italy, Lebanon, Lithuanian, Moldavia, Netherlands, Poland, Serbia, Slovenia, Spain, Switzerland, Tunisia, Turkey, UK, USA, former USSR, former Yugoslavia (Dönel and Doğan, 2013; Fan et al., 2016).

\section{CONCLUSION}

In this study, the diversity and distribution of phytophagous and predatory mites on rosehip plants in Ankara were determined. A total of 125 samples were collected from six districts during two years. A total of 1173 specimens of which 897 specimens belongs to plant feeding mites and the rest was predatory mites. A total of 12 mite species were determined in this study. The six phytophagous mite species were determined to be members of Tetranychidae (A. viennensis, T. urticae, B. kissophila and E. populi), Tenuipalpidae (C. pulcher) and Tarsonemidae (T. smithi) families. T. urticae is the most common and important phytophagous mite species in Ankara. T. smithi is the first record for the Turkish fauna. Six predatory mite species were identified from 276 predatory mite samples examined. Among them five species (K. aberrans, E. finlandicus, T. (A.) bagdasarjani, T. (A.) psyllakisi and $P$. triporus) were belonging to family Phytoseiidae and one species (Z. mali) belonging to family Stigmaeidae.

Although chemical control is the most widely used method in Çubuk among the districts sampled in this study, the highest number of phytophagous mites was determined in this district. However, the number of predatory mites was relatively low when compared to phytophagous mites in Cubuk. The fauna of Gölbașı is different from other districts, probably due to high humidity. Therefore, it harbors various species such as Eotetranychus populi and Tarsonemus smithi. As a result, predatory mites (especially phytoseiid species) were intensively observed in this study. For this reason, they can be used in the pest management programs that are targeting at control of phytophagous mites. Thus, it would also help to reduce total pesticide applications.

\section{Funding}

This study was supported by University of Ankara, the Coordination of Scientific Research Projects (BAP12B4347011).

\section{Conflict of interest}

I declare that there are no conflicts of interest among the authors.

\section{Acknowledgements}

This manuscript is a part of the PhD thesis of T. Erdoğan. We would like to express our sincere gratitude to Ankara University for their financial support to this work.

\section{REFERENCES}

Anonymous, 2007. Available http://www.faunaeur.org (Last accessed: 1 July 2020)

Anonymous, 2014. Available http://www.faydalarizararlari.com/kusburnununfayda-lari/ (Last accessed: 1 July 2020)

Anonymous, 2016. Available http://eunis.eea.europa.eu/species/251989 (Last accessed: 1 July 2020)

Bayram, Ş., Ülgentürk, S. and Toros, S. 1998. Researches on the insects causing galls on dog rose (Rosa spp.) and their parasitoids in Ankara province. Turkish Journal of Entomology, 22: 259-268. [In Turkish]

Çobanoğlu, S., Ueckermann E.A. and Sağlam, H.D. 2016. The Tenuipalpidae of Turkey, with a key to species (Acari: Trombidiformes), Zootaxa, 4097: 151-186. doi: 10.11646/zootaxa.4097.2.1

Demite, P.R., McMurtry, J.A. and Moraes, G.J. de. 2014 Phytoseiidae Database: a website for taxonomic and distributional information on phytoseiid mites (Acari). Zootaxa, 3795: 571-577. doi: 10.11646/zootaxa.3795.5.6

Dönel, G. and Doğan, S. 2013. The first record of a predator mite in Kelkit Valley: Zetzellia mali (Ewing) (Acari: Stigmaeidae). Erzincan University Journal of Science and Technology, 6: 157-163. [In Turkish]

Düzgüneş, Z. 1963. Türkiye'de yeni bulunan akarlar. Türkiye Bitki Koruma Bülteni, 3: 237-246. [In Turkish]

Düzgüneş, Z. 1965. Türkiye'de bitkilerde zarar veren Tenuipalpidae Sayed familyası türleri üzerine incelemeler. Ankara Üniversitesi Ziraat Fakültesi Yıllığı, 3, 120-148. [In Turkish]

Ersin, F. and Madanlar, N. 2016. A new record for the Turkish fauna; Typhlodromus (Anthoseius) psyllakisi Swirski \& Ragusa (Acari: Phytoseiidae). Turkish Journal of Biological Control, 7: 7-12.

Fan, Q.-H., Flechtmann, C.H.W. and Moraes, G.J. de (2016) Annotated catalogue of Stigmaeidae (Acari: Prostigmata) with a pictorial key to genera. Zootaxa, 4176 (1): 1199.

doi: 10.11646/zootaxa.4176.1.1

Faraji, F., Çobanoğlu S. and Çakmak, I. 2011. A checklist and a key for the Phytoseiidae species of Turkey (Acari: Mesostigmata), International Journal of Acarology 37 (sup1): 221-243.

doi: 10.1080/01647954.2011.558851 
Gökçe, M.P., Karagöz, M., Faraji, F. and Cakmak, I. 2020. Mite species composition and their population densities on chestnut trees in Turkey. International Journal of Acarology, 46: 247-253.

doi: 10.1080/01647954.2020.1752796

Jeppson, L.R., Keifer, H.H. and Baker, E.W. 1975. Mites injurious to economic plants. University of California Press, 253-283.

Karaca, İ. 1956. Orta Anadolu ve meyve ağaçlarında görülen menşei nebati ve hayvani önemli urların amili ve morfolojileri hakkında araştırmalar. Ankara Üniversitesi Ziraat Fakültesi Yayınları, 84, Ankara Üniversitesi Basımevi, Ankara, Turkey, 134 pp. [In Turkish]

Meyer, M.K.P. 1987. African Tetranychidae (Acari: Prostigmata). Entomology Memoir Department of Agriculture Technical Service, Republic of South Africa, 69, 175 pp.

Migeon, A., Nouguier, E. and Dorkeld, F. 2011. Spider mites web: a comprehensive database for the Tetranychidae. Trends in Acarology: 557-560. doi: 10.1007/978-90-481-9837-5_96

Özbek, H., Güçlü, Ş. and Tozlu, G. 1996. The harmful arthropod species of Rosa canina in Erzurum, Erzincan,
Bayburt and Artvin provinces. Rosehip Symposium, 56 September, Gümüşhane, Turkey, 219-230.

Papadoulis, G.Th., Emmanouel, N.G. and Kapaxidi, E.V. 2009. Phytoseiidae of Greece and Cyprus (Acari: Mesostigmata). Indira Publishing House, West Bloomfield, Michigan, USA, $200 \mathrm{pp}$.

Pritchard, A.E. and Baker, E.W. 1955. A revision of the spider mite family Tetranychidae. Memoirs Series, San Francisco, Pacific Coast Entomological Society, 2: 472 pp.

doi: 10.5962/bhl.title.150852

Pritchard, A.E. and Baker, E.W. 1958. The false spider mites (Acarina: Tenuipalpidae). University of California Publications in Entomology, 14: 175-274.

Tuttle, D.M. and Baker, E.W. 1968. Spider mites of Southwestern United States and a revision of the Family Tetranychidae. The University of Arizona Press, Tuscon-Arizona, USA, 143 pp.

Edited by: İbrahim Çakmak

Reviewed by: Two anonymous referees

Citation: Erdoğan, T. and Çobanoğlu, S. 2020. Diversity and distribution of phytophagous and predatory mites on rosehip (Rosa canina L.) (Rosaceae) in Ankara, Turkey. Acarological Studies, 2 (2): 83-87. 